\title{
MEMBANGUN BUDAYA ORGANISASI SEBAGAI KEUNGGULAN KOMPETITIF PADA STAF YAYASAN RUHAMA GUNUNG SINDUR
}

\author{
1) Unik Desthiani, ${ }^{2)}$ Annie Rufeidah, ${ }^{3)}$ Sewaka, ${ }^{4)}$ Katry Anggraini, dan ${ }^{5)}$ Rahmayanti \\ Universitas Pamulang \\ dosen02131@unpam.ac.id,dosen01940@unpam.ac.id,dosen00120@unpam.ac.id, \\ dosen02033@unpam.ac.id,dandosen02125@unpam.ac.id
}

\begin{abstract}
The Ruhama Foundation was established on March 23, 2012, located at Jalan Betet 1, Kampung Kebon Kopi, RT 03 RW 06, Pengasinan Village, Gunung Sindur District, Bogor Regency, West Java. Human resources are the important meaning of a reality that every human individual is the most important element because it always exists in an organization. Culture provides an identity for members of the organization and evokes a commitment to beliefs and values greater than oneself. The performance of the foundation staff is the basis for the achievement of the foundation's goals and achievements. Foundation staff form an overall perception based on the characteristics of the organizational culture which include innovation, persistence, aggressiveness, results orientation, people orientation, attention to detail, and team orientation. The organizational culture of the foundation staff in continuously improving performance to consistently carry out their duties and responsibilities in accordance with existing provisions and regulations is expected to continue to develop potential, especially regarding various programs at the Ruhama Foundation, so that foundation staff are expected not only to have good performance, but can do professionally. The success of the foundation's staff performance is not only influenced by organizational culture, but also members of the organization are expected to be able to work together with other members to solve problems that arise in the organization, so it is necessary to establish effective and efficient teamwork within the foundation. With the formation of teamwork, it is hoped that the cooperation of the foundation staff will be higher, so that it will facilitate the achievement of the foundation's goals.
\end{abstract}

Keywords: Organizational Culture, Competitive Advantage, Foundation Staff

\begin{abstract}
ABSTRAK
Yayasan Ruhama berdiri sejak 23 Maret 2012, beralamat di Jalan Betet 1 Kampung Kebon Kopi RT 03 RW 06 Desa Pengasinan Kecamatan Gunung Sindur Kabupaten Bogor Jawa Barat. Sumber daya manusia merupakan arti penting dari suatu realita bahwa setiap individu manusia merupakan elemen yang paling utama karena selalu ada dalam suatu organisasi. Budaya memberikan identitas bagi para anggota organisasi dan membangkitkan komitmen terhadap keyakinan dan nilai yang lebih besar dari dirinya sendiri. Kinerja staf yayasan merupakan dasar bagi pencapaian tujuan dan prestasi yayasan. Para staf yayasan membentuk persepsi keseluruhan berdasarkan karakteristik budaya organisasi yang antara lain meliputi inovasi, kematapan, keagresifan, orientasi hasil, orientasi orang, perhatian ke hal yang rinci, dan orientasi tim. Budaya organisasi staf yayasan dalam meningkatkan kinerja secara berkesinambungan untuk tetap konsisten melaksanakan tugas dan tanggung jawab sesuai dengan ketentuan dan peraturan yang ada diharapkan untuk terus melakukan pengembangan potensi khususnya tentang berbagai program yang ada di Yayasan Ruhama, sehingga staf yayasan diharapkan tidak saja memiliki kinerja yang bagus, tetapi dapat melakukan secara profesional. Keberhasilan kinerja staf yayasan tidak hanya dipengaruhi oleh budaya organisasi, namun juga anggota organisasi diharapkan mampu bekerjasama dengan anggota yang lain untuk menyelesaikan permasalahan yang muncul dalam organisasi, sehingga perlunya dibentuk teamwork yang efektif dan efisien dalam yayasan. Dengan adanya pembentukan teamwork diharapkan akan meningkatkan kerjasama staf yayasan lebih tinggi, sehingga akan memudahkan tercapainya tujuan yayasan.
\end{abstract}




\section{Kata Kunci: Budaya Organisasi, Keunggulan Kompetitif, Staf Yayasan}

\section{PENDAHULUAN}

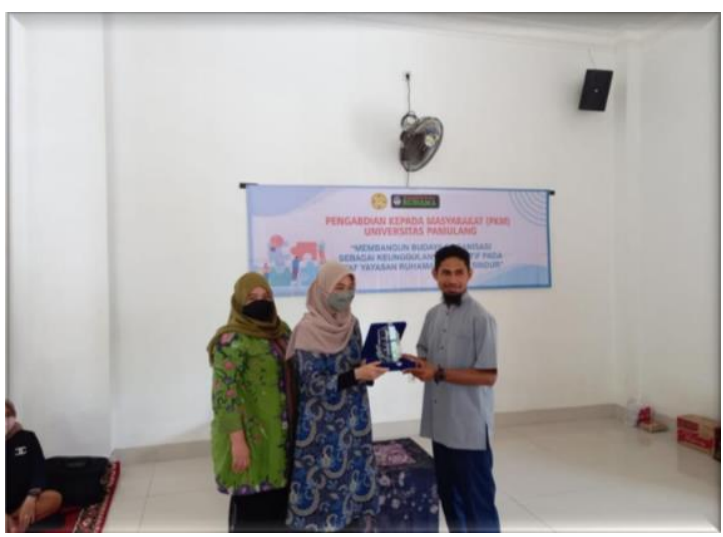

Organisasi adalah suatu unit terkordinasi yang terdiri dari dua orang atau lebih, dan berfungsi mencapai satu sasaran tertentu atau serangkaian sasaran. Organisasi juga sangat berpengaruh dalam peningkatan kualitas sekolah.

Budaya sekolah adalah sekumpulan nilai yang melandasi perilaku, tradisi, kebiasaan keseharian, dan simbol-simbol yang dipraktikkan oleh kepala sekolah, tenaga pendidik, petugas administrasi, siswa, dan masyarakat sekitar sekolah. Menurut Maryamah (2016:1), nilai-nilai dalam budaya sekolah mencakup: kebiasaan hidup, etika, kejujuran, kasih sayang, mencintai belajar, bertanggung jawab, menghormati hukum dan peraturan, menghormati orang lain, mencintai pekerjaan, suka menabung, suka bekerja keras, tepat waktu. Adapun penerapan budaya tersebut di dalam organisasi menjadi budaya 2 organisasi.
Budaya organisasi mewakili persepsi umum yang dimiliki oleh anggota organisasi. Keadaan ini terbentuk secara jelas bila kita mendefinisikan budaya sebagai suatu sistem pengertian bersama. Dengan demikian, kita berharap bahwa masing-masing individu dengan latar belakang atau tingkat jabatan yang berbeda di dalam organisasi akan mendeskripsikan budaya organisasi tersebut dengan cara yang sama. Namun demikian pengakuan bahwa suatu budaya organisasi memiliki properti umum tidak berarti bahwa tidak boleh ada sub budaya di dalam budaya bersama. Kebanyakan organisasi besar memiliki suatu budaya dominan dan sejumlah budaya sub budaya dominan.

Budaya organisasi selain mendukung strategi bisnis perusahaan, budaya organisasi juga sebagai kemajuan suatu bangsa sangat ditentukan oleh kualitas pendidikannya. Oleh karena itu, pendidikan sebagai sarana untuk mencerdaskan kehidupan bangsa memiliki peran yang sangat strategis.

Pendidikan merupakan urusan setiap orang, walaupun tidak semua orang bisa diakui layak untuk berbicara tentang pendidikan. Dalam aspek ini peranan pendidikan memang sangat strategis karena menjadi tiang sanggah dari 
kesinambungan masyarakat itu sendiri. Pendidikan merupakan faktor penting dan menentukan dalam kehidupan berbudaya, berbangsa dan bernegara. Sekolah sebagai lembaga pendidikan sudah semestinya mempunyai organisasi yang baik agar tujuan pendidikan formal ini tercapai sepenuhnya. Dengan demikian organisasi dan budaya sanggat berkaitan dalam tercapainya suatu tujuan. Setiap organisasi mempunyai kepribadian sendiri yang membedakannya dari organisasi-organisasi lain. Tentunya kepribadian yang khas itu tidak serta merta terbentuk begitu suatu organisasi didirikan. Diperlukan waktu sebagai proses organisasi itu bertumbuh, berkembang, dan mapan.

Budaya yang dibangun di sekolah akan menumbuhkan disiplin, etos kerja staf menjadi manusia yang penuh optimis, berani tampil, berperilaku kooperatif dan memupuk rasa tanggung jawab, serta rasa kebersamaan. 8 kedisiplinan yang sangat ditekankan pada staf dan tenaga pendidik yang selalu diciptakan guna terwujudnya sekolah yang berwawasan lingkungan sesuai dengan visi sekolah. Hal tersebutlah yang membuat peneliti mampu mengindikasikan bahwa budaya organisasi di sekolah tersebut cukup baik.

Hal ini akan berdampak pada program kerja serta visi misi sekolah yang inggin dicapai dan diharapkan, sedangkan peran dari budaya organisasi terhadap organisasi, anggota organisasi dan mereka yang berhubungan dengan organisasi adalah identitas organisasi, menyatukan organisasi, reduksi konflik, komitmen, reduksi ketidakpastian, menciptakan konsistensi, motivasi, kinerja organisasi, keselamatan kerja dan sumber keungulan kompetitif. Terkait dengan membangun budaya organisasi di Yayasan Rumah Yatim Piatu dan Pesantren Ruhamah Gunung Sindur-Bogor peneliti ingin mengetahui apakah dengan membangun budaya organisasi mampu membantu sekolah dalam meningkatkan mutu pendidikan di Yayasan Rumah Yatim Piatu dan Pesantren Ruhamah Gunung Sindur-Bogor.

Suatu lembaga sangat memerlukan peran pemimpin yang memiliki ketegasan dan contoh yang baik untuk staf dan tenaga pendidik terutama dalam kaitannya kebiasaan yang dapat menjadi budaya dalam suatu organisasi, hal kecil yang sangat berdampak besar sangat sulit ditemui pada era saat ini. Terkadang organisasi melupakan budaya kecil yang malah mampu membuat suatu organisasi tersebut maju, seperti membudayakan datang tepat waktu dan bila ada anggota yang datang terlambat seharusnya diberikan punishment atau sangsi yang tegas. Maka berdasarkan latar belakang 
yang telah di uraikan, maka penulis tertarik untuk melakukan Pengabdian pada masalah "Membangun Budaya Organisasi sebagai Keunggulan Kompetitif pada Staf di Yayasan Rumah Yatim Piatu dan Pesantren Ruhamah Gunung SindurBogor."

\section{METODE PELAKSANAAN}

Setelah kami melakukan survey ke yayasan RUHAMA dan mengamati apa saja permasalahan yang ada, maka kami sepakat untuk mengambil judul Pengabdian Kepada Masyarakat sebagai berikut: "Membangun Budaya Organisasi sebagai Keunggulan Kompetitif pada Staf Yayasan Ruhama Gunung Sindur". Langkah berikut yang kami lakukan adalah dengan membuat proposal PKM yang kami ajukan kepada LPPM.

Proposal PKM yang diajukan kemudian akan di review oleh reviewer untuk kemudian disetujui oleh ketua LPPM. Setelah proposal PKM disetujui oleh ketua LPPM, maka kami melakukan berbagai persiapan terutama menyiapkan materi yang akan kami sampaikan pada kegiatan Pengabdian Kepada Masyarakat (PKM) untuk lebih mengetahui cara membangun budaya organisasi sebagai keunggulan kompetitif pada staf yayasan RUHAMA Gunung Sindur.

Berikut adalah tahapan-tahapan yang dilakukan oleh dosen pelaksana Pengabdian Kepada Masyarakat (PKM):
Kepada Masyarakat (PKM) dengan fokus

1. Tahap Persiapan

a. Survei awal.

b. Pemantapan dan penentuan lokasi dan sasaran.

c. Penyusunan bahan atau materi meliputi: slide, infokus, dan fotokopi materi.

2. Tahap Pelaksanaan Pelatihan Pada tahap ini akan dijelaskan mengenai bagaimana cara membangun budaya organisasi sebagai keunggulan kompetitif pada staf yayasan RUHAMA Gunung Sindur. Dengan menggunakan metode penyuluhan dan metode Tanya jawab untuk memberikan kesempatan menggali sedalamdalamnya terkait materi yang diberikan.

\section{HASIL DAN PEMBAHASAN}

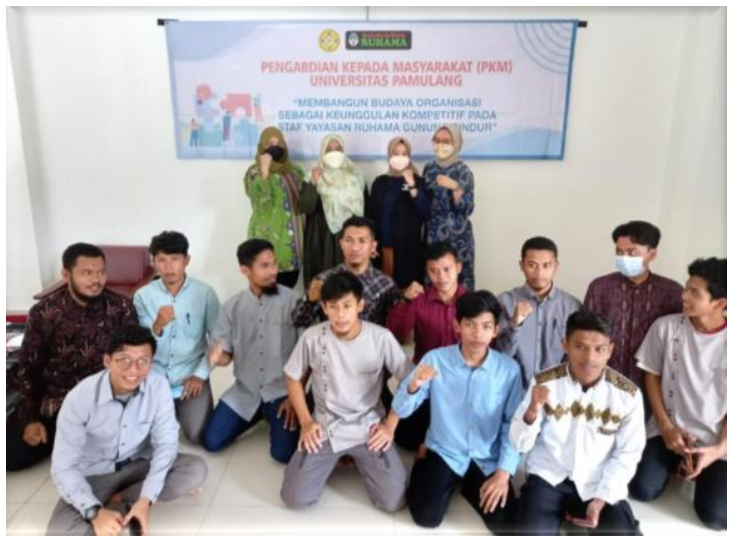

Rumah Yatim \& Pesantren Ruhama adalah rumah dan tempat bernaung bagi anak anak yatim dengan penyantunan dan pemberian pendidikan gratis bagi setiap anak asuh yang dengan kurikulum 
kepesantrenan dan berlokasi di daerah Bogor Yayasan Ruhama berdiri sejak 23 Maret 2012, beralamat di Jalan Betet 1 Kampung Kebon Kopi RT 03 RW 06 Desa Pengasinan Kecamatan Gunung Sindur Kabupaten Bogor Jawa Barat. Keseharian anak-anak diisi dengan kegiatan belajar formal di pesantren pribadi, menghafal AlQuran, dan lain-lain.

Yayasan Ruhama diharapkan bisa menjadi wadah pengembangan dan perbaikan diri bagi para pengurus dan staff yang nota bene masih sangat muda dan perlu banyak bimbingan dari banyak pihak dengan cara belajar langsung di tengahtengah masyarakat yang majmu dan hiterogen.

Mengingat komplek dan luasnya medan kehidupan ini, maka Yayasan Ruhama hanya bergerak pada tiga (3) bidang utama yakni sosial, pendidikan dan dakwah. Dengan hal ini besar harapan kami sebagai pengurus dapat mendapatkan kebahagiaan dunia dan akhirat dengan cara ikut berkiprah dan ambil bagian dalam pembangunan negeri ini dalam bidang sumber daya manusia.

Berikut adalah visi dari Yayasan Rumah Yatim dan Pesantren Ruhama Gunung Sindur yaitu: "Menjadikan lembaga ini sebagai wadah dan sarana yang dapat mengantarkan seluruh pengurus dan masyarakat binaan, mendapatkan ridho Allah sukses bahagia di dunia dan akhirat."

Misi Yayasan Rumah Yatim dan Pesantren Ruhama Gunung Sindur, yaitu:

1. Jangka Panjang Mendapatkan ridho Allah dan masuk syurga.

2. Jangka Menengah Mendapatkan kebahagiaaan dunia dengan ikut berkiprah dalam membangun negeri melalui pembinaan sumber daya manusia.

3. Jangka Pendek Mendidik dan memperbaiki diri dengan cara belajar langsung terjun ke kancah masyarakat yang hiterogen, dengan bimbingan dewan Pembina dan penasehat yayasan, sehingga menjadi pribadi yang senantiasa belajar, beribadah dan bekerja dengan optimal.

Pembahasan dan hasil dari kegiatan Pengabdian kepada Masyarakat ini yaitu antara lain adalah:

1. Cara membangun budaya organisasi sebagai keunggulan kompetitif di Yayasan Rumah Yatim dan Pesantren Ruhama Gunung Sindur

Pada hakekatnya dalam mewujudkan suatu budaya organisasi yang sesuai untuk ditetapkan pada sebuah organisasi, maka diperlukan adanya dukungan dan partisipasi dari semua anggota yang ada dalam lingkup organisasi tersebut. 
Para staf Yayasan Ruhama membentuk persepsi keseluruhan berdasarkan karakteristik budaya organisasi yang antara lain meliputi inovasi, kematapan, keagresifan, orientasi hasil, orientasi orang, perhatian ke hal yang rinci, dan orientasi tim.

Budaya organisasi yang ada selama ini akan berfungsi efektif apabila para staf yayasan dapat menerapkan budaya organisasi sebagai suatu kebiasaan dalam melakukan tugas dengan penuh tanggung jawab.

Budaya organisasi staf yayasan dalam meningkatkan kinerja secara berkesinambungan untuk tetap konsisten melaksanakan tugas dan tanggung jawab sesuai dengan ketentuan dan peraturan yang ada diharapkan untuk terus melakukan pengembangan potensi khususnya tentang berbagai program yang ada di Yayasan Ruhama, sehingga staf yayasan diharapkan tidak saja memiliki kinerja yang bagus, tetapi dapat melakukan secara profesional.

Keberhasilan kinerja staf yayasan tidak hanya dipengaruhi oleh budaya organisasi, namun juga anggota organisasi diharapkan mampu bekerjasama dengan anggota yang lain untuk menyelesaikan permasalahan yang muncul dalam organisasi, sehingga perlunya dibentuk teamwork yang efektif dan efisien dalam yayasan. Dengan adanya pembentukan teamwork diharapkan akan meningkatkan kerjasama staf yayasan lebih tinggi, sehingga akan memudahkan tercapainya tujuan yayasan.

Budaya organisasi unggul bisa juga dibangun berdasarkan pada budaya lokal yang dibentuk berdasarkan unsurunsur budaya lokal yang merupakan warisan budaya leluhur (turun-temurun) di daerah tertentu. Beberapa unsur yang bisa dibangun menjadi budaya orgaisasi adalah nilai-nilai positif (kearifan) dari dinamisasi masyarakat lokal, misalnya cerita (dongeng) rakyat, ritual kedaerahan, tradisi kedaerahan, kreativitas (tari, lagu, drama), dan keunikan masyarakat setempat. Dalam etika atau budaya organsasi yang merupakan bagian ekonomi Islam, tidak lepas dari konsep-konsep Islam (syari'ah) yang harus dilaksanakan dalam bidang tersebut.

Sebuah organisasi mengemban tanggung jawab sosial dalam 3 (tiga) domain:

a. Pada pelaku organisasi

b. Pada lingkungan alam

c. Pada kesejahteraan sosial secara umum 
Karakteristik budaya organisasi Islam yang dapat meningkatkan kinerja organisasi adalah sebagai berikut:

a. Bekerja merupakan "ibadah"

b. Bekerja dengan azas manfaat dan maslahat

c. Bekerja dengan mengoptimalkan kemampuan akal

d. Bekerja penuh keyakinan dan optimistic

e. Bekerja dengan mensyaratkan adanya sikap tawazun (keberimbangan)

f. Bekerja dengan memperhatikan unsur kehalalan dan menghindari unsur haram (yang dilarang syariah)

2. Hambatan yang dialami staf yayasan dalam membangun budaya organisasi sebagai keunggulan kompetitif di Yayasan Rumah Yatim dan Pesantren Ruhama Gunung Sindu

Perbedaan budaya dapat menjadi faktor yang memberikan keunggulan kompetitif. Oleh karena itu, budaya organisasi menjadi penting karena memberikan peluang bagi organisasi untuk membedakan diri dari organisasi lain dan memanfaatkan sumber daya manusianya sebagai elemen keunggulan yang kompetitif. Selain itu, terdapat tantangan yang menghambat terbentuknya budaya di suatu organisasi.
Pada umumnya ada beberapa tantangan dalam pembentukan budaya organisasi antara lain:

a. Akses dalam hal berkomunikasi, misalnya informasi yang diterima masih kurang jelas, dan kurangnya waktu berdiskusi mengenai informasi yang diterima.

b. Adanya kesenjangan generasi, dimana saat ini masuknya generasigenerasi muda atau yang bisa dikatakan generasi milenial yang memiliki pola pikir dan inovasi secara digitalisasi. Oleh karena itu, kesenjangan generasi menjadi tantangan besar di berbagai organisasi, dimana menyebabkan demografi yang lebih luas dan beragam secara digital.

c. Perubahan pola kerja tradisional, dengan adanya perubahan di era globalisasi saat ini, dimana aktivitas banyak dilakukan dengan sistem digitalisasi menyebabkan terjadinya perubahan pola kerja yang harus mengikuti perkembangan saat ini, sehingga seluruh staf dipaksa untuk mengikuti perubahan dan harus terbiasa mengikuti era digitalisasi.

d. Internalisasi nilai-nilai yayasan kepada seluruh staf, terkadang untuk melakukan proses internalisasi nilainilai membutuhkan waktu yang cukup panjang serta kesabaran agar 
setiap staf dapat mengikuti nilai-nilai yang ada di Yayasan.

e. Kesadaran akan pentingnya mengembangkan kemampuan yang dimiliki, hal ini perlu terus diingatkan dan ditingkatkan, untuk dapat bersaing menjadikan yayasan Ruhama dikenal banyak orang dan memiliki keunggulan dan ciri khas yang membedakan dengan yayasan serupa lainnya.

3. Hambatan yang dialami staf yayasan dalam membangun budaya organisasi sebagai keunggulan kompetitif di Yayasan Rumah Yatim dan Pesantren Ruhama Gunung Sindu

Berdasarkan pada tantangan-tantangan yang harus dihadapi Yayasan Ruhama, ada beberapa usaha yang dapat dilakukan untuk membangun budaya organisasi sebagai keunggulan kompetitif, antara lain:

a. Pemimpin Yayasan membutuhkan dukungan dari semua pihak untuk menyelaraskan budaya dan model perilaku yang diharapkan bersama, menjadi role model bagi seluruh staf merupakan cara terbaik untuk memberikan sikap dan perilaku positif yang dapat dicontoh seluruh staf untuk dapat bersaing dalam keunggulan kompetitif. b. Seorang pemimpin harus dapat mengikuti perubahan zaman dimana saat ini, hamper semua aktivitas menggunakan sistem digitalisasi sehingga dengan pemahaman yang sama antara pemimpin dengan anggota timnya akan semakin kuat budaya organisasi yang terbentuk sehingga memiliki kemampuan untuk menghadapi tantangan saat ini.

c. Pemimpin dengan staf harus dapat menyelaraskan hati, pikiran dan tujuan agar sama-sama menjalankan misi untuk pencapaian visi bersama, sehingga saling memotivasi satu sama lainnya untuk mencapai tujuan organisasi sesuai harapan bersama.

\section{KESIMPULAN DAN SARAN}

Berdasarkan dari hasil pembahasan yang telah diuraikan oleh penulis, maka dapat diambil kesimpulan sebagai berikut:

1. Staf Yayasan Ruhama membentuk persepsi keseluruhan berdasarkan karakteristik budaya organisasi yang antara lain meliputi inovasi, kematapan, keagresifan, orientasi hasil, orientasi orang, perhatian ke hal yang rinci, dan orientasi tim. Budaya organisasi yang ada selama ini akan berfungsi efektif apabila para staf yayasan dapat menerapkan budaya 
organisasi sebagai suatu kebiasaan dalam melakukan tugas dengan penuh tanggung jawab. Budaya organisasi staf yayasan dalam meningkatkan kinerja secara berkesinambungan untuk tetap konsisten melaksanakan tugas dan tanggung jawab sesuai dengan ketentuan dan peraturan yang ada diharapkan untuk terus melakukan pengembangan potensi khususnya tentang berbagai program yang ada di Yayasan Ruhama, sehingga staf yayasan diharapkan tidak saja memiliki kinerja yang bagus, tetapi dapat melakukan secara profesional.

2. Pada umumnya ada beberapa tantangan dalam pembentukan budaya organisasi antara lain: akses dalam hal berkomunikasi, adanya kesenjangan generasi, perubahan pola kerja tradisional, internalisasi nilai nilai yayasan kepada seluruh staf, kesadaran akan pentingnya mengembangkan kemampuan yang dimiliki.

3. usaha yang dapat dilakukan untuk membangun budaya organisasi sebagai keunggulan kompetitif, antara lain: Pemimpin Yayasan membutuhkan dukungan dari semua pihak untuk menyelaraskan budaya dan model 43 perilaku yang diharapkan bersama, menjadi role model bagi seluruh staf merupakan cara terbaik untuk memberikan sikap dan perilaku positif yang dapat dicontoh seluruh staf untuk dapat bersaing dalam keunggulan kompetitif, Seorang pemimpin harus dapat mengikuti perubahan zaman dimana saat ini, hamper semua aktivitas menggunakan sistem digitalisasi sehingga dengan pemahaman yang sama antara pemimpin dengan anggota timnya akan semakin kuat budaya organisasi yang terbentuk sehingga memiliki kemampuan untuk menghadapi tantangan saat ini, Pemimpin dengan staf harus dapat menyelaraskan hati, pikiran dan tujuan agar sama sama menjalankan misi untuk pencapaian visi bersama, sehingga saling memotivasi satu sama lainnya untuk mencapai tujuan organisasi sesuai harapan bersama.

\section{DAFTAR PUSTAKA}

A.A. Anwar Prabu Mangkunegara. 2009. Manajemen Sumber Daya Manusia. Bandung: Remaja Rosdakarya.

Anatan. 2010. "Corporate Social Responsibility (CSR): Tunjauan Teoritis Dan Praktik Di Indonesia”. Jurnal Manajemen Universitas Kristen Maranatha. (2010).

Darodjat, Tubagus Achmad. 2015. Pentingnya Budaya Kerja Tinggi \& Kuat. Bandung: PT Refika Aditama.

Edy Sutrisno. 2010. Manajemen Sumber Daya Manusia, Edisi Pertama. Cetakan Pertama. Jakarta: Kencana. 
Hari, Sulaksono. 2015. Budaya Organisasi Dan Kinerja. Yogyakarta: CV Budi Utama.

Http://repository.umy.ac.id/bitstream/hand le/123456789/21786/6.\%20BAB\%

20II.pdf? sequence $=5 \&$ isAllowed $=\mathrm{y}$ - Diakses pada Tanggal 28 November 2021, pukul: 19.00 WIB, hari: Minggu.

Ilmiyati, A., \& Munawaroh, M. 2016. Pengaruh Manajemen Rantai Pasukan Terhadap Keunggulan Kompetitif dan Kinerja Perusahaan. Jurnal Manajemen Bisnis, 226-251. (2016).

Maryamah, Eva. 2016. Pengembangan Budaya Sekolah. Jurnal Tarbawi, Volume 2. (2016).

Moeheriono. 2012. Pengukuran Kinerja Berbasis Kompetensi. Jakarta: Raja Grafindo Persada.

Panbundu, M.T. 2012. Budaya Organisasi dan Peningkatan Kinerja Perusahaan. Jakarta: Bumi Aksara.

Priansa, Donni Juni dan Garnida, Agus. 2013. Manajemen Perkantoran. Bandung: Alfabeta.

Rakhmat, Jalaludin. 2013. Pengertian Staf Terhadap Psikologi Komunikasi di Perkantoran Edisi Revisi. Jakarta: Salemba Empat.

Romli, K. 2014. Pengertian Staf Umum dan Khusus Komunikasi Organisasi Lengkap (Revisi, P. 31). Jakarta: PT Grasindo.

Sadulloh. 2011. Pedagogik (Ilmu Mendidik). Bandung: Alfabeta.

Sedarmayanti. 2014. Sumber Daya Manusia dan Produktivitas Kerja. Jakarta: Mandar Maju.

Torang, Syamsir. 2013. Organisasi dan Manajemen. Cetakan Kesatu. Bandung: CV Alfabeta.

Yuswani, Wiwik. 2016. Pengaruh Budaya Organisasi dan Stress Terhadap Motivasi Kerja Dan Dampaknya Terhadap Kinerja Karyawan Pada PT. Kerinci Pertama Motor Jambi. Jurnal Sainstech Politeknik Indonusa Surakarta. (2016). 